\title{
Bilgisayarlı Tomografik Koroner Anjiyografi ile Erken Evre Koroner Arter Hastalığı Tespit Edilmiş Olan Hastalarda Anksiyete ve Depresyon Düzeylerinin Tespiti
}

\author{
Mustafa Ahmet Huyut ${ }^{1}$, Betül Çetintulum Huyut ${ }^{2}$ \\ ${ }^{1}$ Yeni Yüzyıl Üniversitesi Tıp Fakültesi, Kardiyoloji Anabilim Dalı, İstanbul \\ ${ }^{2}$ Istanbul Arel Üniversitesi, Sosyal Bilimler Enstitüsü, Klinik Psikoloji Doktora Programı, İstanbul
}

\begin{abstract}
Özet
Amaç: Bu çalışmanın amacı kardiyoloji polikliniğine başvurup bilgisayarlı tomografik anjiyografi (BTA) ile erken evre koroner arter hastalığı (KAH) tanısı kesinleşmiş hastalarda anksiyete ve depresyon düzeylerini değerlendirmektir.

Yöntemler: Çalışmaya 46 BTA ile erken evre KAH tanısı alan hasta, 50 kontrol hastası olmak üzere ardışık 96 hasta dahil edildi. Tüm hastaların demografik özellikleri, fizik muayene bulguları, kardiyovasküler risk faktörleri ve laboratuar parametreleri kayıt edilerek Beck Anksiyete Ölçeği (BAÖ) ve Beck Depresyon Ölçeği (BDÖ) uygulandı. Sonuçlar \%95'lik güven aralığında, anlamlılık $\mathrm{p}<0.05$ düzeyinde değerlendirildi.

Bulgular: Çalışmaya katılan olguların 49'u kadın (\%51.04) olmak üzere, ortalama yaşları 35.86 \pm 14.91 yıl olarak bulundu. BTA grubu ile kontrol grubu karşılaştıııldığında BDÖ ölçeği puan ortalamaları arasında anlamlı fark saptandı

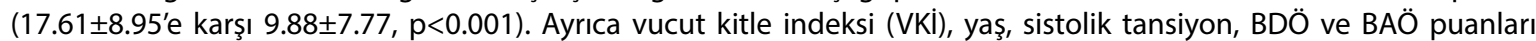
arasında pozitif yönde korelasyon olduğu bulundu. Yaş faktörü, çok değişkenli lojistik regresyon analizi ile erken evre KAH'ın bağımsız öngördürücüsü olarak saptandı ( $\mathrm{OR}=1.45, \% 95 \mathrm{Cl}$ : 1.04-2.03, p=0.028).

Sonuç: BTA ile erken evre KAH tespit edilen hastalarda depresyon düzeylerinin daha yüksek olduğu görüldü.

Anahtar sözcükler: Anksiyete; bilgisayarlı tomografi anjiyografi; depresyon; koroner arter hastalığı.

Determination of Anxiety and Depression Levels in Patients with Early-Stage Coronary Artery Disease Detected with Computed Tomography Coronary Angiography

\footnotetext{
Abstract

Objective: The aim of this study is to evaluate the levels of anxiety and depression in the cardiology outpatient clinic patients diagnosed as early-stage coronary artery disease (CAD) by applying with computed tomography angiography (CTA).

Methods: In this study, consecutive 96 patients were included, 46 patients with CTA which were diagnosed with early-stage $C A D$, and 50 control patients. Demographic features, physical examination findings, cardiovascular risk factors, and laboratory parameters of all patients were recorded. In addition, participants were asked to fill the Beck Anxiety Inventory (BAI) and Beck Depression Inventory (BDI) questionnaires. The results were evaluated at the $95 \%$ confidence interval and the significance level at $p<0.05$.
} 
Results: In the cases involved in the study, 49 (51.04\%) were female and the average age was $35.86 \pm 14.91$ years. BDI results were significantly higher in the CTA group compared to the control group (17.61 \pm 8.95 vs. 9.88 $\pm 7.77, p<0.001)$. In addition, a positive correlation was found between $\mathrm{BDI}$ and body mass index, age, systolic blood pressure, and BAI results. The age factor was found as an independent predictor of early stage CAD with multivariate logistic regression analysis $(\mathrm{OR}=1.45,95 \% \mathrm{Cl}$ : 1.04-2.03, $\mathrm{p}=0.028$ ).

Conclusion: We have shown that depression levels can be higher in patients with early-stage CAD which were detected with CTA.

Keywords: Anxiety; computed tomography angiography; coronary artery disease; depression.

Cite this article as: Huyut MA, Çetintulum Huyut B. Determination of Anxiety and Depression Levels in Patients with Early-Stage Coronary Artery Disease Detected with Computed Tomography Coronary Angiography. Turk J Cardiovasc Nurs 2020;11(26):119-124.

$\mathrm{K}^{\circ}$ oroner arter hastalığı (KAH), erişkin yaşta mortalite ve morbiditenin en önemli nedenlerinden biridir. Dünya Saglık Örgütü verilerine göre, gelişmiş ülkelerde meydana gelen ölümlerin \%48.6'sının nedenini kardiyovasküler kaynaklı hastalıklar teşkil etmektedir. ${ }^{[1]}$ Onat ve arkadaşlarınca yürütülen çalışmada, erişkin nüfusumuzda \%3.8 oranında (erkeklerde \%4.1, kadınlarda \%3.5) KAH tespit edilmistir. ${ }^{[1]}$ Koroner anjiyografi (KAG) işlemi koroner arterlerin anatomisini incelemek ve tanı koymak için günümüzde yaygın olarak kullanılmaktadır. ${ }^{[2]}$ Koroner anjiyografi işlemi esnasında gereklilik halinde aynı seansta perkütan balon anjioplasti ve stentleme işlemi de tedavi amaçlı yapılabilmektedir. ${ }^{[2] ~ K o r o n e r ~ a r t e r ~ h a s t a l ı g ̆ ı ~ t a n ı s ı n d a ~ k u l l a n ı l a n ~ g o ̈ r u ̈ n t u ̈ l e m e ~}$ yöntemleri olarak konvansiyonel KAG, kardiyak bilgisayarI tomografik anjiografi (BTA), manyetik rezonans koroner anjiyografi ve miyokard perfüzyon sintigrafisi sayılabilir. Bilgisayarlı tomografik anjiografide non-iyonik intravenöz kontrast madde enjeksiyonu kullanılarak diyastol sonunda 100 msn altında ardışık ince aksiyel kesitler elde edilmekte ve tek nefes tutumunda tüm kalp ve koroner arterlerin görüntülenmesi sağlanabilmektedir. ${ }^{[3]}$ Literatür incelendiğinde $\mathrm{KAH}$ risk faktörlerinden olan depresyon ve anksiyetenin varlığı konvansiyonel anjiografi yapılan veya kalp krizi geçiren hastalarda saptanmış olup, depresyon ve anksiyetenin $\mathrm{KAH}$ şiddeti ve prevelansı ile ilişkili olduğu bildirilmiştir. ${ }^{[4,5]}$ Bu bulgulara rağmen, hastalara $\mathrm{KAH}$ tanısı konduktan sonra halen ortaya çıkabilecek affektif bozukluklar gözden kaçırılabilmektedir. ${ }^{[4]}$ Bu tür durumların gözden kaçırılmaması ve gerekli psikolojik bakımın hastalara sağlanması önem arz etmektedir. Literatür incelendiğinde KAH ile depresyon arasındaki ilişkiyi koyan çalışmaların konvansiyonel anjiografi ile teşhis almış hasta grubunda yapıldığı görülmektedir. ${ }^{[4]}$ Biz bu çalışma ile, literatürdeki çalışmalardan farklı olarak, BTA ile erken evre KAH saptanmış stent veya bypass operasyonu ihtiyacı bulunmayan hastalarda anksiyete ve depresyon düzeylerini belirleyebilmek ve bunu kontrol grubu ile karşılaştırmak, böylece BTA ile erken tanı alacak hastaların da ihtiyaç duyabilecekleri psikolojik desteğe yönlendirilmelerinin önemli olabileceğini ortaya koymayı amaçladık.

\section{Gereç ve Yöntem}

\section{Araştırmanın Amacı ve Tipi}

Bu çalışma kesitsel tanımlayıcı bir çalışma olup, çalışmanın amacı kardiyoloji polikliniğine başvurup BTA ile erken evre $\mathrm{KAH}$ tanısı kesinleşmiş hastalarda anksiyete ve depresyon düzeylerini değerlendirmektir.

\section{Araştırmanın Evren ve Örneklemi}

Bu çalışma bir hastanenin kardiyoloji polikliniğine ayaktan başvuran bireyler arasında yapıldı. Araştırmanın evrenini bahsedilen hastanenin kardiyoloji polikliniğinde takibi devam eden BTA ile KAH tanısı almış yetişkin hastalar ile sağlıklı bireyler oluşturdu. Araştırmanın örneklemini ise güç analizi ile 0.05 yanılgı, 0.95 güven aralığıyla, evreni 0.95 temsil gücüyle 46 hasta, 50 sağlıklı gönüllü olmak üzere toplam 96 birey oluşturdu. Araştırmaya alınacak hastalar evrenden çalışma şartlarını taşıyan kişilerden seçildi.

\section{Veri Toplama Yöntemi ve Araçlar}

1 Ocak-15 Ağustos 2020 tarihleri arasında, 18 yaş üstü, bir hastanenin kardiyoloji polikliniğine ayaktan başvurmuş bireyler arasından yapıldı. Çalışmaya alınan hastalar kontrol grubu $(n=50)$ ve BTA ile nonkritik erken evre KAH saptanan hastalar ( $n=46$ ) olmak üzere iki gruba ayrıldı. Bilgisayarlı tomografik anjiografi grubuna alınan hastalar stabil koroner arter hastalığı olarak değerlendirilen, bazal seum kreatin seviyesi $1.7 \mathrm{mg} / \mathrm{dl}$ 'nin altında olan, BTA çekilmiş ve koroner arterlerinde müdahale gereksinimi olmayan, plak ile \%70'in altında darlık saptanan $(n=46)$ hasta dahil edildi. Hastalarda aşağıda belirtilen endikasyonlardan en az birinin saptanması halinde BTA çekildi: stabil göğüs ağrısı sendromunun değerlendirilmesi, kardiyak enzimlerin yükselmediği şüpheli ya da nondiyagnostik EKG değişikliklerinin saptandığı, efor testi için egzersiz yapmaya uygun olmayan, şüpheli ya da net olarak değerlendirilemeyen stres testi sonucunun (efor testi, stres eko, miyokart perfüzyon sintigrafisi) varlığı, yeni gelişen kalp yetmezliği olup etyolojiyi ortaya koymak için koroner arterlerin değerlendirilmesinin gerekmesi, ablasyon tedavisi planlanan hastalarda pulmoner ven anatomisinin değerlendirilmesinin gerekmesi, kardiyak 
hipertrofisi olup teknik olarak ekokardiyografi ile yetersiz görüntülerin elde edildiği hastalar olarak sayıldı. Kontrol grubuna, kardiyoloji polikliniğine başvuran, fizik muayene, elektrokardiografi ve ekokardiyografi sonuçlarında iskemi bulgusu düşünmediğimiz, maksimal efor testi yapılan ve iskemik açısından negatif saptanan ( $n=50, \% 100)$, klinisyen tarafından komorbit hastalığı bulunmayan, sağlıklı olarak değerlendirilen 50 hasta dahil edildi. Çalışmaya 18 yaş altı, BTA'da koroner arterlerinde \%70 üzerinde stenoz saptanan, ana koroner arterinde \%50 üzeri lezyon saptanan veya tamamen normal koroner arter saptanan, emziren, gebe veya gebelik şüphesi olan, serum kreatinin seviyesi $1.7 \mathrm{mg} /$ dl ve üzeri olan, son 6 ay içinde antidepresan, anksiyolitik ve/veya antipsikotik ilaç kullanan, herhangi psikiatrik hastalığı olan hastalar dahil edilmedi.

Katılımcılardan Beck Anksiyete Ölçeği (BAÖ) ve Beck Depresyon Ölçeği (BDÖ) doldurmaları istendi. Beck Depresyon Ölçeği depresyon ile ilişkili fiziksel, duygusal, bilişsel ve motivasyonel semptomları değerlendirmek amacıyla Aaron Beck tarafından geliştirilen 21 soruluk dört seçeneği bulunan bir özbildirim ölçeğidir. ${ }^{[6]}$ Beck Depresyon Ölçeğinde 0-9 arası puanlar düşük düzeyde depresif belirtilerin varlığını gösterirken, 10-29 arası puanlar orta düzey, 30-63 arası puanlar yüksek düzey depresyonu işaret etmektedir. Hisli ve ark. 1989 yılında yaptığı çalışmada BDÖ’nnin ülkemiz için geçerli ve güvenilir olduğu gösterilmiştir. ${ }^{[6]}$ Beck Anksiyete Ölçeği ise 21 sorudan oluşan kişide anksiyete şiddetini ölçmek için kullanılan bir özbildirim ölçeği olup ${ }^{[7]}$ BAÖ'nün ülkemiz için geçerlik ve güvenilik çalışması Ulusoy ve ark. tarafından 1998 yılında yapılmıştı. ${ }^{[7]}$

$\mathrm{Bu}$ araştırmada, katılımcıların klinisyen tarafından yapılan rutin fizik muayene bulguları, boy ve kilo bilgileri ve antekubital venden alınan laboratuar kan sonuçları kayıt altına alındı. Vücut kitle indeksi ise ağırlık $(\mathrm{kg}) / \mathrm{boy}^{2}\left(\mathrm{~m}^{2}\right)$ formülü ile hesaplandı. Kan sayımları Sysmex K-1000 (Block Scientific, Bohemia, NY, ABD) otomatik analizörü ile ölçüldü. Numuneler 10 dakika boyunca 3000 rpm'de santrifüjlendi ve süpernatan ve serum numunelerden ayrılarak rutin kan biyokimya sonuçları elde edildi. Bilgisayarlı tomografi görüntüleri ise $80 \mathrm{cc}$ non iyonik, iso-osmolar kontrast madde (iodixanol, Visipaque $320 \mathrm{mg} / 100 \mathrm{~mL}$, GE Healthcare, Cork, Ireland) kullanılarak, 256 kesit single-source dual-energy spectral BT (Revolution Discovery CTA HD, GE Healthcare Technologies, Milwaukee, WI, USA) cihazı ile elde edildi. Sonuçlar aynı kardiyoloji uzmanı tarafından değerlendirildi.

\section{Araştırmanın Etik Yönü}

Araştırma, bir özel hastanenin yönetim kurulu başkanlığından yazılı izin ve bir üniversitenin fen, sosyal ve girişimsel olmayan sağlık bilimleri araştırmaları etik kurulundan (toplantı tarihi: 11.05.2020, karar no: 2020/04-05) etik kurul onayı alınarak yapıldı. Çalışmaya katılan katılımcılardan gönüllü katılım onam formları alındı, çalışma Helsinki ilkeler deklerasyonuna ve iyi klinik uygulamalar etiğine uyularak yapıldı.

\section{Araştırma Verilerinin Değerlendirilmesi}

Çalışmada elde edilen veriler SPSS 22.0 (statistical software, SPSS Inc., Chicago, IL, USA) paket bilgisayar programı kullanılarak değerlendirildi. Sürekli değişkenlerin normal dağılımı Kolmogorov-Smirnov testi ile incelendi, sürekli değişkenleri karşılaştırmak için bağımsız örnekler T-testi veya Mann-Whitney $U$ testi kullanılarak analiz edildi. Sürekli değişkenler normal dağılıma göre ortalama ve standart sapma, normal varsayımı karşılamadıysa medyan ve 25.-75. persantil olarak, kategorik değişkenler ise sayı ve yüzde olarak ifade edildi. Kategorik değişkenler ki-kare testi ile analiz edildi. Değişkenler arasındaki ilişki Spearman korelasyon analizi kullanılarak yapıldı. Tek değişkenli lojistik regresyon analizi yapılarak $\mathrm{p}<0.1$ altında bulunan değişkenler çok değişkenli lojistik regresyon analizine dahil edildi. Bağımsız değişkenin olasıllı oranı ve \%95 güven aralığı hesaplandı. $P$ değeri $<0.05$ olması istatiksel olarak anlamlı kabul edildi.

\section{Araştırmanın Sınırlılıkları}

Birincisi ve bu çalışmanın temel kısıtlılığı, çalışmanın oldukça küçük bir örneklem büyüklüğü ile yapılmasıdır. İkincisi, bu çalışmada kontrol grubuna komorbit hastalıkları olan hastalar alınmaması planlandığı için bu gruba yaş ortalaması nispeten daha düşük bireyler dahil edilmiştir. Bu faktörler çalışmamızın sonuçlarının genellenebilmesini kısıtlamaktadır.

\section{Bulgular}

$\mathrm{Bu}$ çalışmaya kardiyoloji polikliniğine başvuran, katılım şartlarını sağlayan toplam 96 hasta dahil edilmiştir (49 kadın (\%51.04); ortalama yaş: 35.86 14.91 yıl). BTA grubuna 46 hasta (\%47.92) dahil edildi. Katılımcıların demografik özellikleri ve laboratuar verileri Tablo 1'de gösterildi.

Çalışmamızda BDÖ sonuçları BTA grubunda kontrol grubuna göre anlamlı derecede yüksek saptandı $(p<0.001)$. Ayrıca BDÖ ile VKİ, yaş, sistolik tansiyon, BAÖ sonuçları arasında pozitif korelasyon olduğu bulundu (Tablo 2).

Çalışma evrenimizdeki katılımcıların kardiyovasküler risk faktörleri değerlendirildiğinde, erkek cinsiyet, yaş, VKi (kg/ $\mathrm{m}^{2}$ ), sistolik tansiyon BTA grubunda kontrol grubuna göre istatistiksel olarak anlamlı derecede daha yüksek saptandı $(p<0.001)$. Sigara kullanım oranları veya aile öyküsü bakımından gruplar arası fark saptanmadı. Çok değişkenli 


\begin{tabular}{|c|c|c|c|}
\hline Değişkenler, n (\%) & BTA Grubu n=46 (47.92) & Kontrol Grubu $n=50(52.08)$ & $\mathbf{p}$ \\
\hline Erkek cinsiyet, n (\%) & $26(56.52)$ & $16(32)$ & $<0.001$ \\
\hline Evli olma, n (\%) & 39 (84.78) & $7(14)$ & $<0.001$ \\
\hline İşsizlik, n (\%) & $7(15.21)$ & $1(2)$ & 0.033 \\
\hline Sigara, n (\%) & $23(50)$ & $25(50)$ & 1.000 \\
\hline VKI, $\mathrm{kg} / \mathrm{m}^{2}$ & $28(25-28.75)$ & $22(20-24)$ & $<0.001$ \\
\hline Sistolik tansiyon, mmHg & $141.44 \pm 20.18$ & $113.28 \pm 11.11$ & $<0.001$ \\
\hline Diastolik tansiyon, $\mathrm{mmHg}$ & $80.39 \pm 11.46$ & $74.20 \pm 9.26$ & 0.014 \\
\hline Üre, mg/dl & $25.95(22.10-33.40)$ & $22.10(18.25-26.27)$ & 0.027 \\
\hline Kreatinin, mg/dl & $0.75(0.59-0.83)$ & $0.62(0.57-0.73)$ & 0,005 \\
\hline Eritrosit 106/uL & $4.68 \pm 0.62$ & $4.74 \pm 0.40$ & 0.583 \\
\hline Trombosit $10^{3} / \mathrm{uL}$ & $238.86 \pm 49.01$ & $252.58 \pm 50.38$ & 0.211 \\
\hline BDÖ & $17.61 \pm 8.95$ & $9.88 \pm 7.77$ & $<0.001$ \\
\hline BAÖ & $11.50 \pm 10.07$ & $8.90 \pm 8.45$ & 0.184 \\
\hline
\end{tabular}

Değişkenler ortalama \pm standart sapma ya da sayı ve yüzde olarak verildi. Kategorik değişkenlerin p-değeri Chi-square testi ile elde edildi. Non-kategorik değişkenleri değerlendirmek için normal dağılanlar T-testi ile, normal dağılmayanlar Mann-Whitney U testi ile değerlendirildi. BTA: Bilgisayarlı tomografik anjiyografi; ALT: Alanin aminotransferaz; AST: Aspartat aminotransferaz; BAÖ: Beck anksiyete ölçeği; BDÖ: Beck depresyon ölçeği; eGFR: Ortalama glomerüler filtrasyon hızı; VKi: Vücut kitle indeksi.

\begin{tabular}{lcc}
$\begin{array}{l}\text { Tablo 2. Beck depresyon ölçeği ile aralarında korelasyon bulunan } \\
\text { değişkenler }\end{array}$ & $\mathbf{r}$ & $\mathbf{p}$ \\
\hline Değişkenler & 0.359 & $<0.001$ \\
\hline VKi & 0.368 & $<0.001$ \\
Yaş & 0.369 & $<0.001$ \\
Sistolik tansiyon & 0.630 & $<0.001$ \\
BAÖ &
\end{tabular}

BAÖ: Beck anksiyete ölçeği; r: Spearman korelasyon katsayısı; VKi: Vücut kitle indeksi.

lojistik regresyon analizi yapıldığında evrenimizdeki katılımcılarda yaş faktörü, erken evre KAH'ın bağımsız öngördürücüsü olarak saptandı $(\mathrm{OR}=1.45,95 \% \mathrm{Cl}: 1.04-2.03$, $\mathrm{p}=0.028)$.

\section{Tartışma}

Çalışmamızda BTA grubunda erken evre KAH saptanan hastaların depresif duygudurumu anlamlı derecede yüksek olarak bulundu. Ayrıca evrenimizdeki katılımcılarda yaş faktörü erken evre KAH'ın bağımsız öngördürücüsü olarak saptandı.

Bilgisayarlı tomografik anjiografi ile koroner arterlerdeki kalsiyumun görüntülenmesi, yüksek rezolüsyonlu volüm modunda gerçekleştirilmekte ve yapılan araştırmalarda BTA'nin KAH saptama duyarlıığının \%92 ve özgüllük değe- rinin \%94 olduğu gösterilmiştir. ${ }^{[8]}$ Ayrıca, daha önceki çalışmalarda BTA ile koroner arter kalsifikasyonu saptayabilme sensitivitesi $\% 95$, spesifitesi \%66 olarak bulunmuştur. ${ }^{[9]} \mathrm{Bu}$ bulgular BTA'nin erken dönem KAH teşhisi koymada çok önemli bir noninvazif tanı yöntemi olduğunu göstermektedir. Klasik anjiografi sonucunda KAH tanısı alan hastalarda yapılan çalışmalarda depresyonun miyokardiyal enfarktüs ve kardiyovasküler mortalite için bağımsız bir risk faktörü olduğu bildirilmiştir. ${ }^{[10]}$ Ayrıca KAH tanılı hastalarda anksiyete ve depresyon düzeylerinin yüksek olduğu bilinmektedir. ${ }^{[1,12]}$ Dolayısıyla KAH depresyonu tetikleyebilmekte, depresyon da KAH'a neden olabilmektedir. Depresif duygudurum, sigara içmeye, azalmış fiziksel aktiviteye, aşırı yeme sonucunda obeziteye ve tedaviye uyumun azalmasına neden olduğu ve $\mathrm{KAH}$ seyrini olumsuz etkileyerek mortalite artışına neden olduğu bilinmektedir. ${ }^{[13,14]}$ Çalışmamızda da literatür ile uyumlu olarak VKI, BTA grubunda anlamlı olarak daha yüksek saptandı. Ayrıca BTA grubunda istatistiksel olarak anlamlı orta düzeyde-yüksek BDÖ sonuçları saptandı. Bu sonuca dayanarak, depresif duygudurumun erken dönem kardiyovasküler hastalıklar için önemli bir risk faktörü olduğu düşünülebilir. Depresif duygudurumun kardiyovasküler sistem üzerindeki etkilerini açıklamak için kullanılan patofizyolojik mekanizmalar; nöroendokrin sistemde bozulma, azalamış parasempatik aktivite, buna 
karşın artmış sempatik aktivite nedeniyle kalp kasının aşırı uyarılması ve sonuç olarak kan basıncı artışı ve vasküler direncin artışı olarak gösterilmektedir. ${ }^{[15-20]}$ Ayrıca, nöroendokrin sistemde meydana gelen sempatik aktivite lehine bozulma, kan kortizol düzeylerinde artışa, plazma ve idrar katekolamin düzeylerinde artışa, trombosit fonksiyon bozukluğuna, artmış lökosit adezyon ve agregasyonuna, inflamatuar sitokinlerin artmasına neden olmaktadır. ${ }^{[16-23]}$ Artmış sempatik aktivite ayrıca kardiyovasküler sistemde köpük hücre oluşumunu ve makrofajların kolesterol alımını inhibe ederek vasküler düz kas hücrelerin proliferasyonunu artırır, lenfositlerden salınan sitokinlerin artışı ile endotel hücrelerinde adezyon moleküllerinin üretimini sağlanarak ateroskleroz gelişimini tetikler. ${ }^{[23-27]}$ Bu faktörlerin birleşmesi ile endotel fonksiyonları bozulmakta, böylece koroner arterlerde ateroskleroz gelişmektedir. ${ }^{[17,27-31]}$ Ayrıca literatüre bakıldığında tedavi gereksinimi olan $\mathrm{KAH}$ olgularında daha yüksek kan basıncı düzeylerinin saptandığı gözlenmiştir. ${ }^{[18,29-31]}$ Bu faktörlerin yanında depresif duygudurum ile tetiklenen nöroendokrin sistemin insulin direnci arışı ile metabolik sendrom riskini artırdığı, obezite, kanser, Tip 2 diabetes mellitus ve hipertansiyon gibi birçok hastalık için de risk faktörü olduğu görülmektedir. ${ }^{[23-27]}$ Çalışmamızda da erken dönemde KAH saptanan BTA grubunda istatistiksel olarak anlamlı daha yüksek sistolik kan basıncı düzeyleri saptandı. Çalışmamız göstermektedir ki erken evre KAH saptanan vakalarda depresif duygudurum, kontrol grubu ile karşılaştııılığında, anlamlı derecede daha yüksek saptanmaktadır. Bu durum hastaların nöröendokrin sistemini aktive etmekte ve bu yol ile sistolik kan basıncında artışa, açlık glukoz seviyelerinde yükselmeye neden olmaktadır. Bu mekanizmalar da aterosklerozun ilerlemesine neden olmaktadır. Çalışmamızın diğer çalışmalardan farkı erken evre $\mathrm{KAH}$ saptanan hastalarda da benzer bulguların olduğunu ortaya koyabilmesidir. Erken evre KAH BTA ile çok başarılı bir şekilde tepit edilebilmektedir. Çalışmamızın bulguları, BTA ile erken dönemde KAH tanısı almış hastaların uygun ölçekler kullanılarak değerlendirilmesinin ve erken dönemde uzman yardımı almalarının gerekli olduğunu ortaya koymaktadır. Erken psikolojik yönlendirme ile hastalık seyrinin ilerlemesinin önüne geçilebileceğini düşünmekteyiz.

Anksiyetenin kardiyovasküler bozuklukların gelişiminde rol oynadığı bilinmektedir. ${ }^{[19,24-26]}$ Anksiyete, her an kalp krizi geçirme kaygısıyla hastaların yaşam kalitesini düşürmekte, sağlık hizmetlerini gereksiz yere kullanmalarına neden olmaktadır. ${ }^{[20,26]}$ Çalışmamızda BTA grubu kontrol grubu ile karşılaştııılığında, görece daha yüksek anksiyete oranları saptanmasına rağmen, gruplar arasında istatistiksel olarak anlamlı fark saptanmadı. Bu sonuç örneklem hacminin kü- çük olması veya sosyodemografik özelliklerin farklı olması neticesinde ortaya çıktığını düşünmekteyiz.

Tüm bu bulgular değerlendirildiğinde, KAH'da depresyon varlığı hastaların tedaviye uyumunu azaltmakta ve hastalığın ilerlemesine neden olmaktadır. ${ }^{[21,22,29]}$ Bu nedenle $\mathrm{KAH}$ ile ilgilenen sağlık çalışanlarına büyük sorumluluklar düşmektedir. Erken dönemde KAH tanısı almış hastalar uygun ölçekler kullanılarak değerlendirilmeli, depresif duygudurumun varlığı söz konusu ise erken dönemde uzman yardımı almaları sağlanmalıdır.

\section{Sonuç}

Sonuç olarak, yaptığımız bu çalışma ile BTA ile erken evre $\mathrm{KAH}$ saptanan hastalarda depresyon düzeylerinin yüksek olduğunu ve bu hastalarda psikolojik değerlendirmenin önemli olduğunu gösterdik. Bu açıdan klinik pratikte kullanımı kolay BDÖ testinin kullanılmasının faydalı olabileceğini düşünmekteyiz. Böylece hastaların ihtiyaç duyabilecekleri psikolojik desteği almaları sağlanarak, hastalarda ortaya çıkabilecek affektif bozuklukların önüne geçilebileceğini düşünmekteyiz. Ayrıca, KAH'ın ilerleyişinin yavaşlatılabileceğini ve hastaların tedaviye uyumlarının arttırılabileceğini, hastaların hayat kalitesinin artmasının sağlanabileceğini de düşünmekteyiz. Bu çalışma verilerinin desteklenmesi için daha büyük ölçekli, randomize kontrollü, uzun takip sürelerine sahip çalışmaların varlığına ihtiyaç duyulmaktadır.

Teşekkür: Yazarlar, değerli katkılarından dolayı hastane yönetimine çok teşekkür eder.

Etik Kurul Onayı: İstanbul Yeni Yüzyıl Üniversitesi Fen, Sosyal ve Girişimsel Olmayan Sağlık Bilimleri Araştırmaları Etik Kurulu. Karar No: 2020/04-05; toplantı tarihi: 11.05.2020.

Hakem Değerlendirmesi: Dış bağımsız.

Çıkar Çatışması: Yazarlar arasında herhangi bir çıkar çatışması bulunmamaktadır.

Yazarlık Katkıları: Konsept: M.A.H.; Dizayn: M.A.H.; Veri Toplama veya İşleme: M.A.H.; Analiz veya Yorumlama: M.A.H., B.Ç.H.; Literatür Arama: B.Ç.H.; Yazan: M.A.H., B.Ç.H.

\section{Kaynaklar}

1. Onat A, Karabulut A, Esen AM, Uyarel H, Özhan H, AlbayrakS, et al. TEKHARF Çalışması 2005 taramasına ilişkin mortalite ve koroner olay analizi. Turk Kardiyol Dern Ars 2006;34(3):14953.

2. Uzun S, Vural H, Uzun M, Yokusoglu M. State and trait anxiety levels before coronary angiography. J Clin Nurs 2008;17(5):602-7. [CrossRef]

3. Erdoğan N, Altın L, Altunkankitap Ş. Elektron beam tomografi ile koroner arterlerde kalsiyum miktarının saptanması. Türk Tanısal ve Girişimsel Radyoloji Dergisi 2002;8(4):533-7. 
4. Sunbul M, Zincir SB, Durmus E, Sunbul EA, Cengiz FF, Kivrak T, et al. Anxiety and Depression in Patients with Coronary Artery Disease. Klinik Psikofarmakoloji Bulteni 2013;23(4):345-52.

5. Scalco AZ, Scalco MZ, Azul JB, Lotufo Neto F. Hypertension and depression. Clinics (Sao Paulo) 2005;60(3):241-50. [CrossRef]

6. Hisli N. Beck depresyon envanteri'nin üniversite öğrencileri için geçerliği, güvenirliği Psikoloji Dergisi 1989;7:3-13.

7. Ulusoy M SN, Erkmen H. Turkish Version of the Beck Anxiety Inventory: Psychometric Properties. J Cogn Psychother 1998;12:163-72.

8. Achenbach S. Quantification of coronary artery stenoses by computed tomography. JACC Cardiovasc Imaging 2008;1(4):472-4. [CrossRef]

9. Budoff MJ, Achenbach S, Blumenthal RS, Carr JJ, Goldin JG, Greenland $\mathrm{P}$, et al. Assessment of coronary artery disease by cardiac computed tomography: a scientific statement from the American Heart Association Committee on Cardiovascular Imaging and Intervention, Council on Cardiovascular Radiology and Intervention, and Committee on Cardiac Imaging, Council on Clinical Cardiology. Circulation 2006;114(16):1761-91. [CrossRef]

10. Rosengren A, Hawken S, Ounpuu S, Sliwa K, Zubaid M, Almahmeed WA, et al; INTERHEART investigators. Association of psychosocial risk factors with risk of acute myocardial infarction in 11119 cases and 13648 controls from 52 countries (the INTERHEART study): case-control study. Lancet 2004;364(9438):953-62. [CrossRef]

11. Dickens CM, McGowan L, Percival C, Tomenson B, Cotter L, Heagerty $A$, et al. Contribution of depression and anxiety to impaired health-related quality of life following first myocardial infarction. Br J Psychiatry 2006;189:367-72. [CrossRef]

12. Frasure-Smith $N$, Lespérance F. Depression and other psychological risks following myocardial infarction. Arch Gen Psychiatry 2003;60(6):627-36. [CrossRef]

13. Ford DE, Mead LA, Chang PP, Cooper-Patrick L, Wang NY, Klag MJ. Depression is a risk factor for coronary artery disease in men: the precursors study. Arch Intern Med 1998;158(13):1422-6. [CrossRef]

14. Bush DE, Ziegelstein RC, Tayback M, Richter D, Stevens S, Zahalsky $\mathrm{H}$, et al. Even minimal symptoms of depression increase mortality risk after acute myocardial infarction. Am J Cardiol 2001;88(4):337-41. [CrossRef]

15. Smith TW, Gerin W. Social psychophysiology of cardiovascular response: An introduction to special issue. Ann Behav Med 1998;20:243-6. [CrossRef]

16. Grippo AJ, Johnson AK. Biological mechanisms in the relationship between depression and heart disease. Neurosci Biobehav Rev 2002;26(8):941-62. [CrossRef]

17. Ross R. Atherosclerosis--an inflammatory disease. N Engl J Med 1999;340(2):115-26. [CrossRef]

18. Krantz DS, Kop WJ, Santiago HT, Gottdiener JS. Mental stress as a trigger of myocardial ischemia and infarction. Cardiol Clin
1996;14(2):271-87. [CrossRef]

19. Sirois BC, Burg MM. Negative emotion and coronary heart disease. A review. Behav Modif 2003;27(1):83-102. [CrossRef]

20. Strik JJ, Denollet J, Lousberg R, Honig A. Comparing symptoms of depression and anxiety as predictors of cardiac events and increased health care consumption after myocardial infarction. J Am Coll Cardiol 2003;42(10):1801-7. [CrossRef]

21. Aydemir Y, Doğu Ö, Amasya A, Yazgan B, Ölmez Gazioğlu E, Gündüz H. Kronik Solunum ve Kalp Hastalıklarında Anksiyete ve Depresyon Sıklığı ve İlişkili Özelliklerin Değerlendirilmesi. Sakarya Med J 2015;5(4):203-199. [CrossRef]

22. Huyut M. The Relationship Between Serum Urotensin II Level and Contrast-Induced Nephropathy and One-year Clinical Follow-up Findings in Patients with Coronary Slow Phenomenon Undergoing Percutaneous Coronary Intervention. Sakarya Med J 2019;9(3):442-54. [CrossRef]

23. Çıtlık Sarıtaş S, Çevik Aktura S. Bilinçli Farkındalık, Kalp Yetersizliği Olan Hastaların Hastane Anksiyete-Depresyon Düzeyini Etkiler Mi? Turk J Cardiovasc Nurs 2020;11(24):1-6. [CrossRef]

24. Kutlu R, Özberk DI, Demirbaş N. Kardiyoloji yoğun bakım ünitesinde yatan hastalarda anksiyete ve depresyon sıklığı ve etki eden faktörler. Turk Gogus Kalp Dama 2016;24(4):672-9.

25. Yel P, Ünsar S. Quality of Life and Anxiety Levels of Patients with Coronary Angiography. Turk J Cardiovasc Nurs 2020;11(24):715.

26. Celano CM, Suarez L, Mastromauro C, Januzzi JL, Huffman JC. Feasibility and utility of screening for depression and anxiety disorders in patients with cardiovascular disease. Circ Cardiovasc Qual Outcomes 2013;6(4):498-504. [CrossRef]

27. Tomita T, Yasui-Furukori N, Sugawara N, Ogasawara K, Katagai $\mathrm{K}$, Saito $\mathrm{H}$, et al. Prevalence of major depressive disorder among hemodialysis patients compared with healthy people in Japan using the Structured Clinical Interview for DSM-IV. Neuropsychiatr Dis Treat 2016;12:2503-8. [CrossRef]

28. Janssen I, Powell LH, Matthews KA, Jasielec MS, Hollenberg SM, Bromberger JT, et al. Relation of Persistent Depressive Symptoms to Coronary Artery Calcification in Women Aged 46 to 59 Years. Am J Cardiol 2016;117(12):1884-9. [CrossRef]

29. Khan A, Palka J, Joshi PH, Khera A, Brown ES. Association of depressive symptom severity with coronary artery calcium: The Dallas heart study. J Affect Disord 2020;276:267-71.

30. Carroll AJ Ms, Auer R, Colangelo LA, Carnethon MR, Jacobs DR Jr, Stewart JC, et al. Association of the Interaction Between Smoking and Depressive Symptom Clusters With Coronary Artery Calcification: The CARDIA Study. J Dual Diagn 2017;13(1):43-51. [CrossRef]

31. Ali SS, Khan SA, Khosa F, Aneni EC, Jones A, St Leger AS, et al. Noninvasive assessment of subclinical atherosclerosis in persons with symptoms of depression. Atherosclerosis 2017;264:92-9. [CrossRef] 